\title{
BRONCHOSCOPY BY THE ANAESTHETIST
}

\author{
David J Power, M.B , B CH, B A.O, F.R.C P (C), F.F A.R.C S., \\ DA (ENG), DA (AM BDS.) *
}

TODAY EVERY ANAESTHETIST is familiar with the technique of direct laryngoscopy The wide use of endotracheal tubes has necessitated that this technique be mastered at a very early stage in training On the other hand, bronchoscopy is still approached as a major difficulty by many anaesthetists. The object of the tollowing paper is to present: a technique of bronchoscopy that hes been found of value for the needs of the anaesthetist. It is the author's opmion $t$ at diagnostic and most therapeutic bronchoscopies belong to the field of either the thoracic surgeon or the otolaryngologist, while the anaesthetıst finds his place in what might be termed for the most part-" torlet bronchoscopies." The same detal of examination and the same complexity of apparatus are not demanded for the latter

\section{Preoperatwe}

\section{INDICATIONS}

This group includes not only wet cases for thoracic operations but also many non-thoracic cases which remain wet despite medicinal and physio-therapeutic measures. Some of these can be adequately aspirated with a catheter via an endotracheal tube, but there remain a number where bronchoscopy is necessary The procedure is also necessary for the introduction of bronchial blockers and endobronchial tubes of a cerain type

\section{Operative}

Occasionally during ling surgery massive shifting of secretions, because of inadequate isolation, may result in encroachment on bronchi to the functioning lung Therr position or character may make emoval by ordinary suction catheter impossible and necessitate bronchoscopy The aspiration of foreign material such as blood or vomitus usually demands immediate bronchoscopy The silent aspiration of acid gastric contents may occur during anaesthesia, and even if suspected may not be evident in physical signs untıl some time after operation (I)

\section{Postoperative}

Immediate postoperative bionchoscopy is carled out almost as a routine by many anaesthetists after lung resection Other wet-lung patients, especially those with upper abdominal incisions, and those in deblitated"condition, will be liable to retain secretions after operation because of meffective cough, and will benefit from a thorough bronchial tollet before being transferred to their bed

Postoperative atelectasis is liable to follow any operation and any anaesthetic technique, but is commoner after upper abdominal operations (2) The collapse may not occur for twenty-four to forty-erght hours and is most likely to occur where pre-existing respuratory infection was present (3) Adequate preoperative and postoperative bieathing exercises, broncho-dilators, and antibiotics will do

"St Mary's Hospital, and Department of Anaesthesıa, McGill University, Montreal P Q 
much to reduce the incidence of this complication When it has occurred and conservative methods have falled to dislodge the obstruction, aspiration of the trachea and bronchi by means of a rubber catheter introduced blindly through the nose and vocal cords will often be effective Somettmes this farls because the catheter does not reach the blocked bronchus, and at times it may be contraindicated, for example, with patients in shock or cardiac fallure The violent coughing evoked by the catheter plus the suction of air from the lungs may result in acute anoxia with all its serious sequelae In such cases a carefully planned bronchoscopy will be less of an ordeal for the patient

\section{AnAesthesia}

Adequate relaxation of the mouth and neck muscles plus suppression of the pharyngeal, laryngeal, tracheal, and bronchial refleses must be obtained The procedure may be performed under etther local or general anaesthesia If it is an immediate preoperatıve or postoperative manipulation and general anaesthesia is the choice for operation, then it can be done while the patient is asleep. Otherwise the mental attitude of the patient may demand general anaesthesia Local analgesia is ideal for bronchoscopy and if properly carried out will render the undertaking simple for the anaesthetsst and not unp.easant for the patient It is the technique most appropriate for postoperative atelectasis, allowing bronchoscopy to be performed with ease in the patient's room and being applicable even to the critically 1 ll

The author uses the following technique for topica analgesia. Before operation the patient receives pentobarbital gi $1-3$ at ninety minutes, and morphia gr $1 / 6-1 / 4$ with atropine gr $1 / 100$ at sixty minutes Either the barbiturate or the morphia or both may be omitted if the condition of the patient contraindicates their use

The patient is put in the semi-recumbent position and the mouth and pharynx are sprayed with Xylocaine 4 per cent, an attempt being made to direct some towards the glottis Four ml of solution should suffice for this. Now the patient is asked to hold his own tongue forward-grasped in a piece of gauze. Many operators hold the tongue themselves, but undue tension and unnecessary distress may be avorded by gettng the patient to assist here A small pledget of gauze held in a curved Krause's forceps is soaked in Xylocame 4 per cent and passed over the tongue and down the lateral wall of the pharynx untl it slips into the pyriform fossa It is not necessary to view the fossa for this manœuvre, as the tip of the forceps can be felt from the outside when it is in the correct position It should lie just below the top of the hyord bone If the patient gags, he should be instructed to breathe deeply through his mouth to depress the reflex The pledget is held in contact with the mucosa for two minutes and then the process is repeated on the other side

Now with the head extended, the upper border of the cricoid cartılage is identified A no 21 needle attached to a $2 \mathrm{ml}$ syringe filled with 4 per cent Xylocaine is inserted through the cricold membrane. The skin puncture is made to one side of the mid-line and puncture of the membrane in the mid-line When the needle-point is in the larynx, which is indicated by the free aspiration of air 
into the syringe, the patient is asked to take a deep breath and then exhale completely. Near the end of exhalation the contents of the syrmge are quickly injected and the needle withdrawn The anaesthetic solution is carried upwards to the vocal cords and excites the cough reflex As the patient is in full expiration at this time, the mitial response is a deep inspiratory gasp which carries the anaesthetic solution down into the bronchial tree (4).

If the patient is edentulcus, a swab soaked in the -anaesthetic solution is placed firmly aganst the gums for a few mmutes as pressure of the bronchoscope on the gums, should it occur, will cause acute discomfort

The patient is now ready for bronchoscopy and it should be explained to him that a tube is to be passed into his windpupe and while it is there he will be unable to speak $\mathrm{He}$ is instructed to relax and to breathe quietly through his mouth at all tumes If the bronchoscopy is to be performed on the operating table, it is usual to have the patient in the supine position If the procedure is carned out in bed, it is more easily done with the patient sitting up, supported by pillows, the operator standing on a stool behind the head of the bed.

\section{EQUIPMENT}

The basic equipment consists of a bronchoscope and an apparatus for suction. The aim is to visualize the trached, the main bronchi, and the orifices of the secondary bronchi The suction appliance consists of a long piece of metal tubing to the distal end of which is attached a prece of not too rigid tubing material which can be bent in different directions so that it can be inserted into the orifices of the secondary bronchi The diagnostic bionchoscopist uses expensive telescopes to view the orifices and the secondary bronchı as a lesion may be out of view of d'irect bronchoscopy For the anaesthetist's part, suction at the orifices will usually clear any obstruction and the character of the arr entry, as heard with a stethoscope, will demonstrate if patency of the bronchus has been re-established

Although a no. 7 bronchoscope is adequate for bronchoscopy in the adult, a no 9 bronchoscope can be used on nearly all adults and has the added advantage of being wide enough to admit a Magill blocker A Thompson blocker needs a no 11 bronchoscope Suckling ( $41 \mathrm{~mm}$ ) and Infant $(54 \mathrm{~mm})$ types are obtainable There are special bronchoscopes for the introduction of endobronchial tubes. Most hospital bronchoscopes are powered from a battery which connects with the light-carner via a lead Portable bronchoscopes with a handle containing a battery can be obtained, but have the disadvantage of being top-heavy and difficult to control when inserted The author prefers the Negus bronchoscope. It is light in construction and conical in shape enabling one to get a clear view without having to peer down a long straight tubular shaft Because of its wide proximal end it will take a large-bore endotracheal tube whereby artificial respiration can be carned out in the apnoerc patient

\section{TECHNique}

Ideally, to faclitate passing the bronchoscope through the glottis, the patient should lie with the neck flexed and the head extended. This position can be secured by placing a small pillow under the nape of the neck 
The patient's eyes are covered with gauze for protection. The mouth is held open with the left hand (Fig. 1), the thumb being behind the lower teeth and the left index finger behind the upper gingival margın. The bronchoscope, held

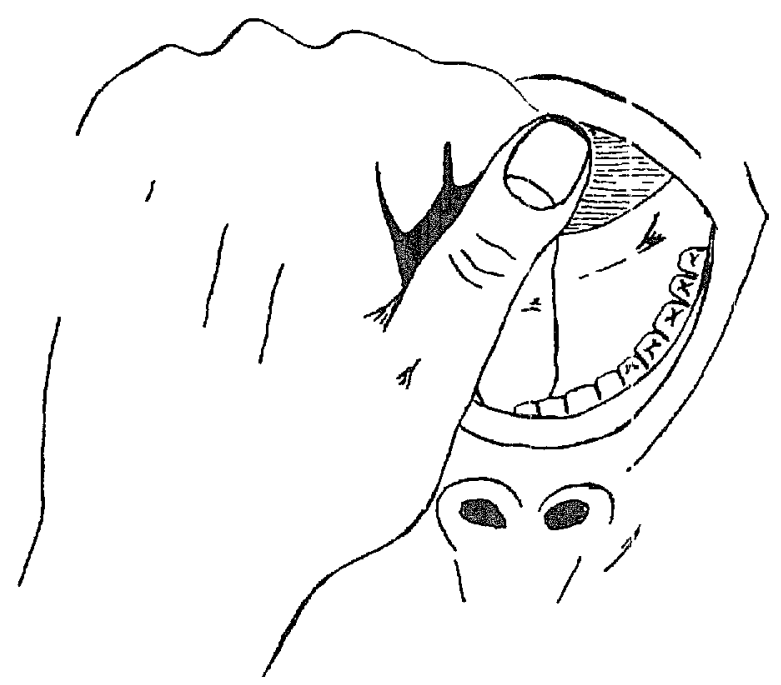

Figure 1. Position of left hand during insertion of bronchoscope into mouth. Left thumb holds the mouth open whle the index finger keeps the heaci in extension Bronchoscope is passed down the right side of the mouth

in the right hand, is inserted at the right side of the mouth, pushing the tongue to the left. When the posterior pharyngeal wall is visualized, the left thumb is slipped under the bronchoscope and pushes it away from the upper teeth. The thumb is maintained in this position throughout the procedure to prevent pressure on the upper teeth or gums (Fig 2) Traction with the left index finger will extend the head and bring the epiglottis into view This is lifted up with the tip

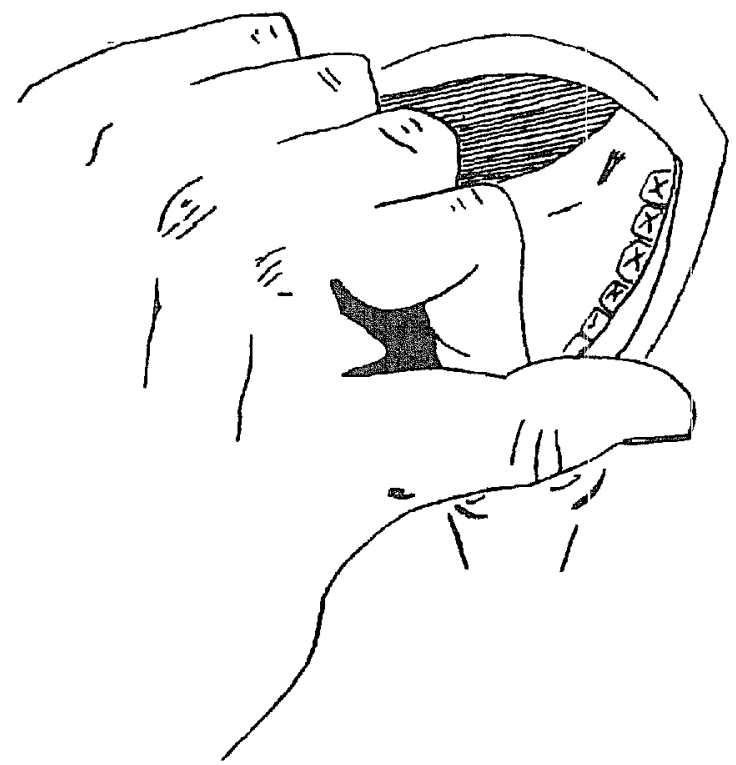

FIGURE 2 Bronchoscope rests against the left thumb which protects the upper teeth Index finger controls the head 
of the bronchoscope, and further pressue upwards with the left thumb combined with further extension of the head by the left index finger will expose the cords. In the adequately anciesthetzzed patient these will be open. Throughout this part of the procedure the tip of the bronchoscope has been directed anteriorly

The bronchoscope is now rotated through 45 degrees to the right, and the aperture of the instrument centred over the left cord. This will bring the tip of the bronchoscope directly over and in line with the glottic opening (Fig. 3). The instrument is now passed into the trachea and the tip brought to the front

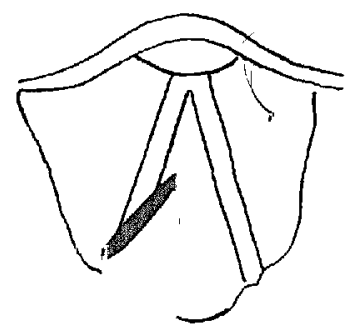

Figune 3 Orientation of bronchoscope for passage through glottis

again At this stage of the operation the ideal position is combined extension of the patient's head and neck To obtam this extended position the pillow under the neck is slipped down until it lies under the shoulders. Further advancement will bring the carma into view. Secretions are aspirated as one advances.

To enter either the right or left bronchus the head is turned sharply to the opposite side; this serves to bring the instrument into the line of the required bronchus. The orifices of the secondary bronchi are identified as one advances, and the tp of the suction apparatus, bent in the desired direction, can be inserted into them to remove the obstructing material

The right upper lobe orfice will be seen on the lateral wall of the right main bronchus usually about $1-2 \mathrm{~cm}$. from the carina. About $2-3 \mathrm{~cm}$. further down, the orfice of the middle lobe on the right is identified on the anterior wall of the bronchus and the superior segmental orifice of the right lower lobe on the posterior wall Below this the bronchi to the basal segments of the right lower lobe will be seen

On the left side, the orifice of the left upper lobe is found about $5 \mathrm{~cm}$. from the carina on the lateral wall. At a corresponding distance on the posterior wall is found the orifice of the superior segment of the left lower lobe. About 1-2 cm below this the main bronchus divides into the basal segmental bronchi of the left lower lobe.

For poor risk patients or those under general anaesthesia, whose respirations may be depressed, oxygen may be led into the bronchoscope via the side-arm on the instrument. 
When gastric contents of a fluid nature have been aspirated, it is not unusual to find no foreign material on bronchoscopy. However, the chemical irritation of the inspired acid contents may result in diffuse bronchiolits followed by collapse. It is the author's practice in these cases to instil into each main bronchus $3 \mathrm{ml}$. of an alkaline solution, for example, alevaure or a 3 per cent sodium bicarbonate solution With coughing this will diffuse throughout the bronchial tree and serve to neutralize the acidity and forestall bronchiolitic changes

\section{COMMENT AND SUMmakY}

Bronchoscopy is a technique easily mastered by the anaesthetıst It can at times be life-saving and at other times reduce postoperative morbidity. The necessary apparatus is simple and can be part of the equipment of any anaesthetic department Diagnostic bronchoscopy belongs to the field of the thoracic surgeon and the otolaryngologist, but by perfecting themselves in the technique of "tollet bronchoscopy" anaesthetists can offer therr patients greater protection and safer anaesthesia.

The indications for bronchoscopy by the anaesthetist and the technical procedure are outlined The necessary equipment and anaesthesia are brieflv discussed.

The author would like to thank Dr G A P Hurley for his help and encouragement in the preparation of this paper

RÉSUMÉ

Tandıs que la bronchoscopie diagnostique est du domame du chirurgien thoracique et de l'otolaryngologiste, l'anesthésiste, lu1, doit se perfectionner dans la toilette bronchique.

Sont candidats pour la bronchoscopie tous les cas de poumons "humides" avant, durant ou après l'opération, et les cas d'atélectasie pulmonare postopératoire

On peut employer l'anesthésıe générale ou locale L’auteur décrit la technique de l'anesthésıe locale Il emploie la Xylocame à 4 pour cent Il en vaporise la bouche et le pharynx $\mathrm{Il}$ anesthésie les terminaisons du nerf laryngé interne en plaçant un tampon de "gauze" imprégné de Xylocaine au moyen d'une pince de Krause dans les fosses pyriformes Une injection transtrachéale de $2 \mathrm{ml}$. de la solution permet d'anesthésier la portion basse du système respiratoire. Cette injection doıt se faire à la fin d'une expiration forcée Sı le patient n'a pas de dents, on placera durant quelques minutes un tampon imprégné de Xylocaine sur les gencives

L'équipement principal comprend un bronchoscope et un appareil à succion Un bronchoscope numéro 9 est adéquat pour la plupart des bronchoscopies chez les adultes. On emploiera des bronchoscopes plus petits pour les enfants et les bébés L'auteur préfère le bronchoscope Negus L'appareil à succion doit être assez malléable pour pouvorr être introduit dans les orıfices des bronches secondaires quand elles sont répérées

La position idéale pour introduire le bronchoscope dans la glotte est la flexion du cou et l'extension de la tête, ce qui peut être obtenu en plaçant un oreiller 
sous la nuque du patient L'extension du cou et de tête sont requises cuand le bronchoscope est en place dans la trachée. On obtient cette dernière pcsition en glissant l'oreiller sous lés épaules du patient.

La main droite tient le bronchoscope et la gauche contrôle la bouche et la tête du patient, et en même temps protège ses dents (Figs. 1 et 2).

La pointe du bronchoscope doit être centrée au-dessus de la glotte avant d'être introduite dans le larynx (Fig. 3).

On identifie la bifurcation des bronches en tournant la tête carrément d'un côté, cecı permet d'introdure le bronchoscope dans la bronche du côté opposé. Les orffices des bronches secondaires sont identifiées. On aspire les sécrétions de la trachée, des bronches et des orifices des bronches secondaires.

Si toutefois de l'acide gastrique a été inspiré, on instille dans chacune des bronches principales $3 \mathrm{ml}$ d'une solution alcaline

\section{REFERENCES}

1 Parker, R. B Brit Med J, 2 65 (1954)

2 Collins, V T. Pnnciples and Practice of Anesthesiology, p 332 Philadelphia Lea \& Febiger (1952).

3 Harris, T A B. The Mode of Action of Anaesthetics, p 552 Edinburgh E. \& S. Livingston Ltd. (1951).

4 LEE, J ALFRED Personal communication 